Horst Kremers Editor
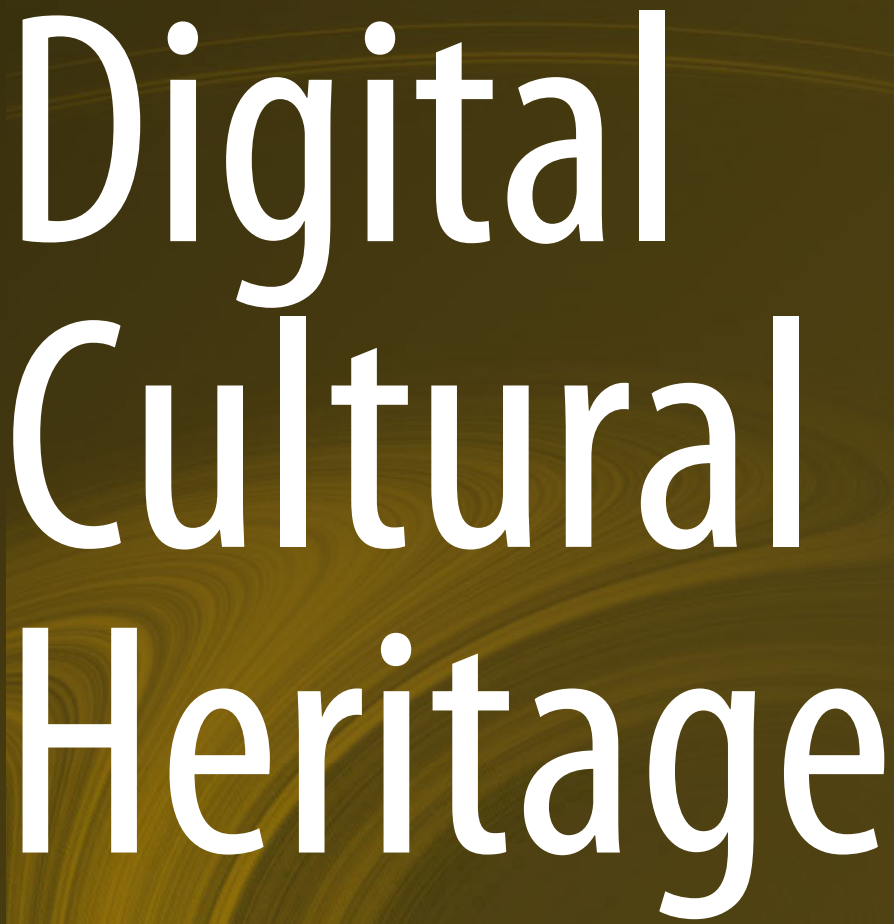

Springer 


\section{Digital Cultural Heritage}


Horst Kremers

Editor

Digital Cultural Heritage

望 Springer 


\title{
Editor
}

\author{
Horst Kremers \\ CODATA-Germany \\ Berlin, Germany
}

ISBN 978-3-030-15198-0

ISBN 978-3-030-15200-0 (eBook)

https://doi.org/10.1007/978-3-030-15200-0

Library of Congress Control Number: 2019935838

\section{(C) Springer Nature Switzerland AG 2020}

This work is subject to copyright. All rights are reserved by the Publisher, whether the whole or part of the material is concerned, specifically the rights of translation, reprinting, reuse of illustrations, recitation, broadcasting, reproduction on microfilms or in any other physical way, and transmission or information storage and retrieval, electronic adaptation, computer software, or by similar or dissimilar methodology now known or hereafter developed.

The use of general descriptive names, registered names, trademarks, service marks, etc. in this publication does not imply, even in the absence of a specific statement, that such names are exempt from the relevant protective laws and regulations and therefore free for general use.

The publisher, the authors and the editors are safe to assume that the advice and information in this book are believed to be true and accurate at the date of publication. Neither the publisher nor the authors or the editors give a warranty, expressed or implied, with respect to the material contained herein or for any errors or omissions that may have been made. The publisher remains neutral with regard to jurisdictional claims in published maps and institutional affiliations.

This Springer imprint is published by the registered company Springer Nature Switzerland AG The registered company address is: Gewerbestrasse 11, 6330 Cham, Switzerland 


\section{Contents}

Augmenting Network Analysis with Linked Data

for Humanities Research

Jörn Kreutel

A Memorial Design Pattern Catalogue for Commemorative

Digital Culture

Susanne Haake, Wolfgang Müller and Marc Wolf

Annotation in Digital Humanities

Federico Caria and Brigitte Mathiak

Establishment of a Complex Database for the Study of Cultural

Heritage Through the Reading and Analysis of the Traditional

Architecture of Upper Kama

Sandro Parrinello and Federico Cioli

Urban History Research and Discovery in the Age of Digital

Repositories. A Report About Users and Requirements .

Sander Münster, Florian Niebling, Jonas Bruschke, Kristina Barthel,

Kristina Friedrichs, Cindy Kröber and Ferdinand Maiwald

Digital Infrastructures for Digital Humanities in International

Textbook Research . . . . . . . . . . . . . . . . . . . . . . 85

Ernesto William De Luca and Christian Scheel

Fusing International Textbook Collections for Textbook Research . . . . 99

Christian Scheel and Ernesto William De Luca

Digital Preservation of Cultural Heritage for Small Institutions . . . . . 109

Rolf Däßler and Ulf Preuß

Body as Echoes: Cyber Archiving of Buddhist Deities in the Cave

Temples of China

Wu-Wei Chen 
A Multivariate Use of Digital Cultural Heritage: Online Resources for Archaeology in the DBAS-MUSINT Websites

(University of Florence, Italy).

Maria Emanuela Alberti, Cristian Faralli and Anna Margherita Jasink

Rebuilding the Past: 3D Reconstruction and BIM Analysis

of a Neolithic House at La Draga (Girona, Spain)

Joan A. Barceló, Michele Calvano, Ivan Campana, Raquel Piqué,

Antoni Palomo and Josep O. Bultó

3D Modeling Applications to Terracotta Figurines

from Plakomenos, Greece.

Dimitra Sarri and Effie F. Athanassopoulos

Virtual Collection of Cuneiform Tablets as a Complex Multilevel

System with Interdisciplinary Content

Petr Zemánek, Jana Mynářová, Petra Štefcová and Jaroslav Valach

The Potentials of the Digital Cultural Heritage: A Best Practice

Example of Presentation and Use. The Digital Representation

of the Hans Gross Kriminalmuseum

Bernadette Biedermann

Planning for the End from the Start: An Argument for Digital

Stewardship, Long-Term Thinking and Alternative Capture

Approaches for Digital Content

Somaya Langley

Semantic Data-Modeling and Long-Term Interpretability

of Cultural Heritage Data-Three Case Studies

Laura Albers, Peggy Große and Sarah Wagner

From Classic (Analogue) to Digital Forms of Cultural Heritage

Protection in Poland.

Barbara Prus, Karol Król, Krzysztof Gawroński, Edward Sankowski and Józef Hernik

Visual Content Analysis and Linked Data for Automatic Enrichment of Architecture-Related Images

Tino Mager, Seyran Khademi, Ronald Siebes, Carola Hein, Victor de Boer and Jan van Gemert

Libraries, Archives, and Museums Interwoven in the Digital South: From a Paucity of Resources to Data Richness for Understanding the South Asian Subcontinent James Nye

Cultural Heritage Digital Data: Future and Ethics

Filippo Diara 
The Cartography Project: Towards a Relational Form of Documentation, the Case of Participatory Art Practices in Museums and Art Galleries .

Gabriella Giannachi, Rebecca Sinker, Steve Benford, Acatia Finbow, Helena Hunter, Valentina Ravaglia, Emily Pringle and Tony Glover

Digitization of Old Maps and Possible On-line Tools for Their Use . . . 331 Milan Talich

Efoto Hamburg: From Image Data to a Digitally Mediated Cultural Heritage Process .

Mareike Schumacher

3D Sketching of the Fortified Entrance of the Citadel of Aleppo

from a Few Sightseeing Photos.

Jean-Baptiste Barreau, Emmanuel Lanoë and Ronan Gaugne

The Integrated Survey of the Pergamum by Nicola Pisano

in the Cathedral of Pisa .

Giovanni Pancani and Matteo Bigongiari

Virtual Representation of Archaeological Stratigraphy. 3D Modeling and Interactive Presentation of the Late Roman Towers

(Archaeological Museum, Milan Italy)

Simona Morandi and Marco Tremari

Opening up Research Data in Film Studies by Using the Structured Knowledge Base Wikidata . . . . . . . . . . . . . . . . . . . . . . . . 401

Adelheid Heftberger, Jakob Höper, Claudia Müller-Birn and Niels-Oliver Walkowski

Gamification in Cultural Heritage: A Tangible User Interface Game for Learning About Local Heritage

Ferdinando Cesaria, Anna Marina Cucinelli, Giuseppe De Prezzo and Italo Spada

Quasi-Mixed Reality in Digital Cultural Heritage. Combining 3D Reconstructions with Real Structures on Location-The Case of Ancient Phalasarna

Gunnar Liestøl and Elpida Hadjidaki

Digitization of Acoustic Heritage in a Service of Protection, Research and Promotion of European Cultural Heritage . Zorana Đorđević, Marija Dragišić, Maria Cristina Manzetti and Dragan Novković 


\title{
A Multivariate Use of Digital Cultural Heritage: Online Resources for Archaeology in the DBAS-MUSINT Websites (University of Florence, Italy)
}

\author{
Maria Emanuela Alberti, Cristian Faralli and Anna Margherita Jasink
}

\begin{abstract}
Since many years the Aegean Laboratory of the SAGAS Department of the University of Florence, Italy, is building two flexible containers of online resources, the Data Bases about Aegean Subjects (http://dbas.sciant.unifi.it/) and the Aegean Museum (http://www.aegean-museum.it/) websites. The contents are related to the archaeology of the Bronze Age Aegean (Greece, 3000-1000 BCE). Together, they are a good example of the multiple potential of Digital Cultural Heritage. Their various parts aim to different targets and audiences, including tools for scholarly research, teaching materials for University classes, and dissemination and interaction contents for a wider public. An overview of the websites is presented here, to stress the connection between the various levels and especially between academic contents and wider dissemination. The main aim of the Aegean Laboratory (@egean$\mathrm{Lab}$ ) is indeed to provide a way to explore various aspects of the Bronze Age Aegean that work for both an academic user and a young pupil. In addition, the cooperation between University and Museums offers access to various collections that otherwise would not be available for the wider public. All this is something that only the Digital Cultural Heritage can ensure. The present paper focuses on the relevant elements of the two websites: the presence of specialized Data Bases, that are therefore freely searchable from anyone, whilst used at the same time for scholarly purposes; 3D representations of the archaeological materials, embedded in the Data Bases and explorable; study tools of various types, from University lessons to didactic panels; contents aimed at the younger visitors, with attractive drawings, reconstructions, videos, games and an interactive tale to complete. All this is the result of the cooperation of various institutions and of a wide range of specialists, from archaeologists to architects and designers to computer scientists and primary school teachers. In the
\end{abstract}

M. E. Alberti $(\bowtie) \cdot$ A. M. Jasink

Dipartimento SAGAS, Università di Firenze, Via San Gallo 10, 50129 Florence, Italy

e-mail: memalberti@gmail.com

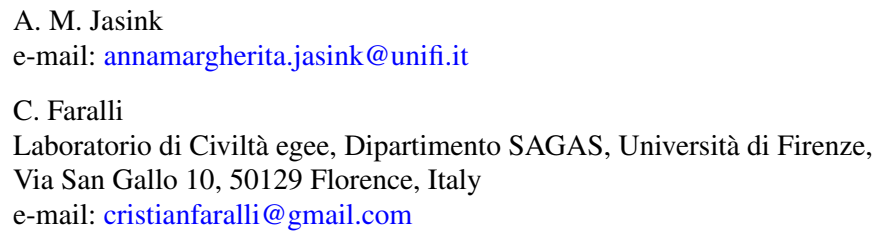


DBAS-Databases about Aegean Subjects, databases span from the Cretan Hieroglyphic Seals and Aegean Cushion Seals to the Ahhiyawa Question and Mycenaeans in the Amarnian Egypt, passing by the Textile Work Areas in Bronze Age Crete (the latter still under construction). In the two main sections of the Aegean Museum website, MUSINT I and II, a larger range of the Digital Cultural Heritage potentials are exploited. MUSINT I gathers in a virtual interactive museum the Aegean materials from various Museums in Tuscany, combining 3D representations of the objects, technical reports and databases. Somehow similar is MUSINT II, that presents in various ways some particular findings from Minoan Crete, the sealings from Haghia Triada. Those stored in Italy are searchable through a database that links once again the scientific records of the Museums of Florence and Rome with 3D representation and scholarly comments. The didactic and interactive part is particularly developed here. The paper will present in detail some databases and an interactive tale that are presently being implemented, to foster the discussion on methodological issues and best practices. Though the Aegean Museum is still under development, it can provide a good example of the Digital Cultural Heritage potential in combining various kinds of tools, expertise, builders and users, bringing together the specialized scholar and the curious pupil, research work and dissemination, and creating a substantial impact in the way we study and perceive antiquity.

Keywords Databases $\cdot$ Interactive museums $\cdot$ Story-telling $\cdot$ Bronze Age Crete Archaeology

\section{Introduction}

DBAS_—egeanLab (http://dbas.sciant.unifi.it/) starts in 2005 as the web-portal of the Laboratory of Aegean Civilisations of the University of Florence. ${ }^{1}$ With the name of 'Data Bases about Aegean Subjects', it was initially created as an online resource containing tools for scientific consultation, such as highly specialized Databases $[14,15,16]$. Along the years it developed in something more complex and includes now a wider range of contents, especially digitalization of museum collections and excavation materials, with scientific and educational aim [17, 19-21]. Consequently, we decided to maintain the same acronym while changing the whole name in 'Digital Bank on Aegean Subjects' (Fig. 1).

Actually, the visitor may also start from a second portal, MUSINT (http://www. aegean-museum.it/) (Fig. 2), especially devoted to create interactive Aegean museums, where objects coming from different sites and collections are often presented as $3 /$ dimensional models.

\footnotetext{
${ }^{1}$ M. E. Alberti and A. M. Jasink contributed to the arguments, the structure and the organization of the present article. The first author wrote paragraphs 3. 4. 5; the second wrote paragraphs 1.2a. 5 ; C. Faralli wrote $2 \mathrm{~b}$ and the other digital contents. The authors warmly thank Giulia Dionisio for her help in the editing process.
} 

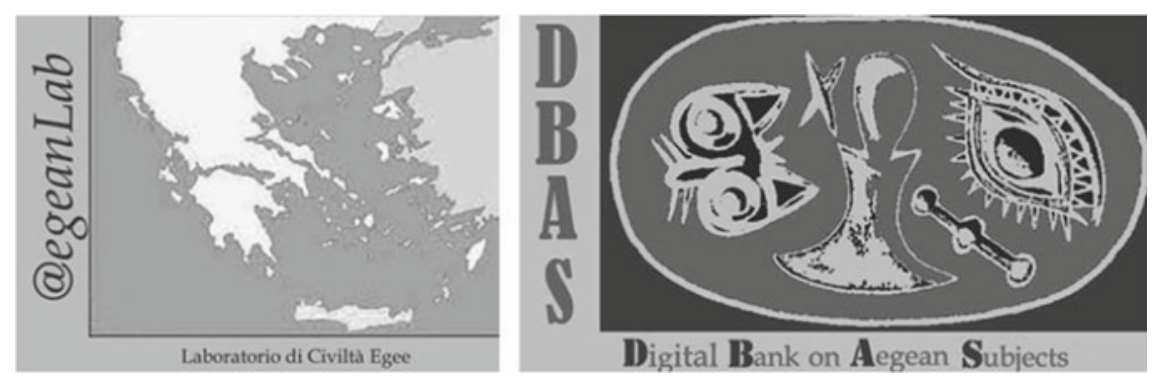

Fig. 1 The Homepage logotype of DBAS—@egeanLab

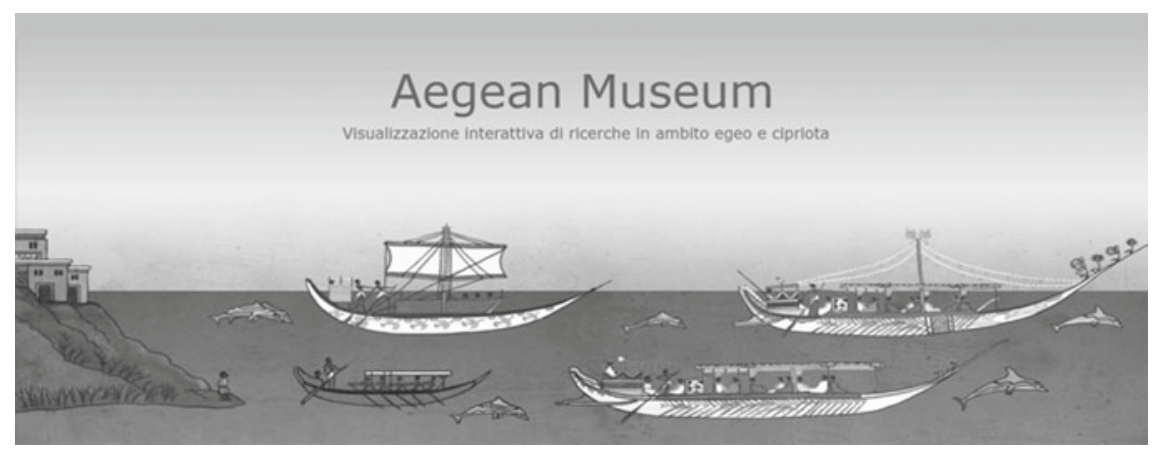

Fig. 2 The Homepage of MUSINT

Both these containers are good examples of the multiple potential of Digital Cultural Heritage. The on-line resources created by DBAS-MUSINT about the societies of the Bronze Age Greece, Crete and Aegean in general (3000-1000 BCE/from the third to the beginning of the first millennium BCE) open a field of research, but the specialists of Bronze Age Aegean, though largely using the new technologies, remained substantially out of the main stream of the discussion. Actually, despite the debate on the complex link between digitization and archaeology/ancient history is presently quite extended, involving various branches of the antiquities, the Aegean field is only marginally affected.

The main aim of DBAS-MUSINT is to present together and connect resources for academic research and resources for a wider public, covering educational contents. Research, didactics and interaction are the key-words. The sites actually include tools for scholarly research, teaching materials for University classes, and dissemination and interaction contents for a wider public and school pupils [18]. Most of the resources are conceived for an active use by the audience: interrogating databases, performing games, answering questions and choosing pathways in the tale.

In addition, they illustrate in the best way how University and Museums can cooperate within the Digital Cultural Heritage. They provide various online resources 


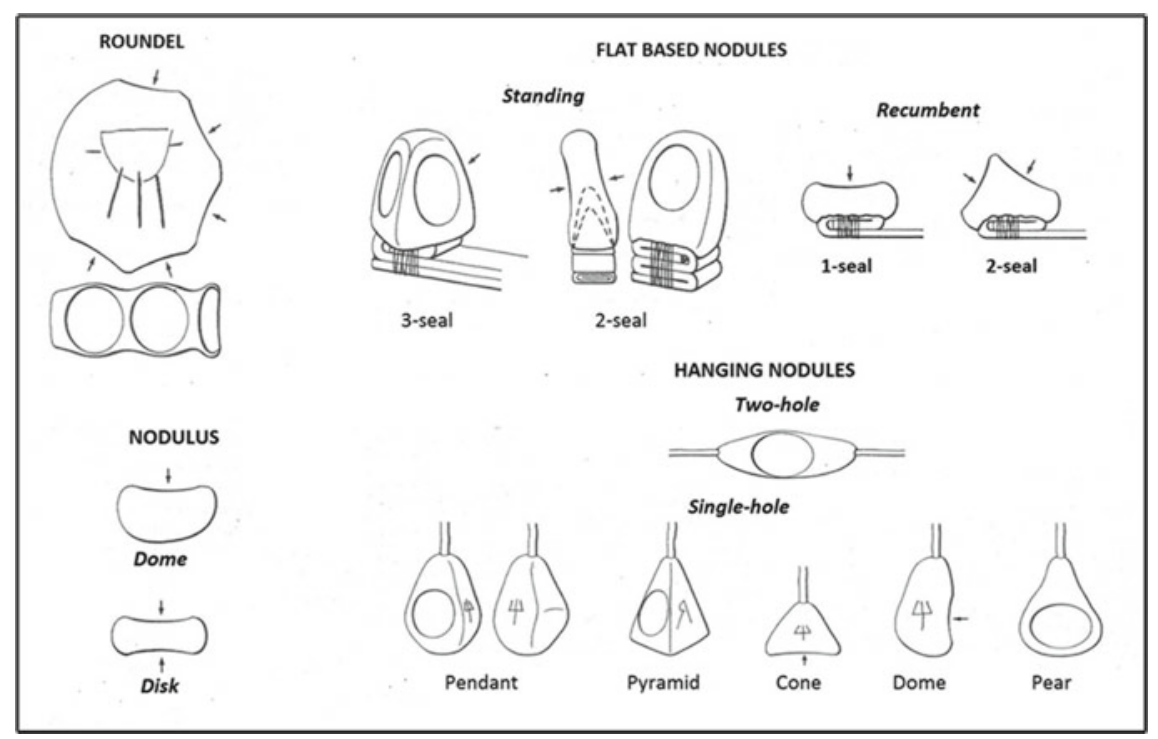

Fig. 3 Cretulae from Haghia Triada and other Minoan sites

to explore contextually the materials of various Museums that could not be seen together otherwise.

In this paper we decided to focus on three sections chosen from the two websites, that are in our opinion good examples as for methodology and best practice. The first is a database on the cretulae from the Villa of Haghia Triada (Fig. 3), that puts together all these small objects discovered in this site.

This database is included in DBAS (in the English version) and in MUSINT II (in both English and Italian versions). The second is a database on textile work areas which will soon appear on DBAS. The third is an interactive story-telling concerning the reconstruction of a 'special' day and events occurred at HaghiaTriada, and is included in MUSINT II.

\section{DB-HTS (Acronym for Database on Haghia Triada Sealings)}

DB-HTS is the new database on the DBAS web-portal and improves considerably the study of the Haghia Triada sealed documents: it concerns not only the cretulae collected in two Italian Museums, the Archaeological Museum of Florence and the Pigorini Museum of Rome, where many objects have been transferred from Haghia Triada and Phaistos during the excavations of the Italian Expeditions in Crete at the beginning of the twentieth century, but also the whole of the cretulae which remained 


\begin{tabular}{|c|c|c|c|}
\hline No. Cat. A & \multirow{2}{*}{\multicolumn{2}{|c|}{\begin{tabular}{|l|}
117 \\
117
\end{tabular}}} & SEAL IMPRESSION \\
\hline No. CMS II,6 & & & \\
\hline Occurrences & \multicolumn{2}{|l|}{38} & \\
\hline Museum & \multicolumn{2}{|c|}{$\begin{array}{l}\text { HMs } 461 / 1-24,462 / 1-6,463 / 1-2.579 \\
\text { MAF 94759. } 94760 \\
\text { RMP 71964. } 71975.71966\end{array}$} & \\
\hline No. AT/Levi & \multicolumn{2}{|c|}{19} & \\
\hline No. Cat. B & \multirow{2}{*}{\multicolumn{2}{|c|}{$\begin{array}{l}81,101,110 \\
\text { Single-hole hanging nodule }\end{array}$}} & \\
\hline Shape & & & 18 pendant, 1 cone \\
\hline Motif & Animal - bird & A standing water bird to left & $\mathrm{ft}$, surrounded by vegetal motifs. \\
\hline Seal's shape & \multicolumn{3}{|c|}{ Convex lentoid soft stone pierced along the vertical axis } \\
\hline Inseriptions & $\begin{array}{l}A B S 1 \mathrm{KU}(\mathrm{Wa} 1471-1622) \\
A B 77 \mathrm{KA}(\mathrm{Wa} 1322-1470)\end{array}$ & \multicolumn{2}{|c|}{$\begin{array}{l}\text { HMs 461/1-24, 462/1-6 (Wa 1562-1591), 463/2 (Wa } 1593), 579 \text { (Wa 1614), } \\
\text { MAF 94759. 94760 (Wa 1557-1558), RMP 71964-71966 (Wa 1559-1561) } \\
\text { HMs 463/1(Wa 1422) }\end{array}$} \\
\hline Notes & \multicolumn{3}{|c|}{$\begin{array}{l}\text { The engraved symbol AB } 81 K U \text { presents several "variants", some of which could been interpreted as different signs rather } \\
\text { than variants. } \\
\text { The impression is of the same hand as No. } 73 \text { (monkey) and No. } 132 \text { (fish) }\end{array}$} \\
\hline
\end{tabular}

Fig. 4 Example of a Cat. A number

in Crete and may be found in the Heraklion Museum. ${ }^{2}$ This is a unique possibility for scholars to see all these materials together and we will illustrate it better in a while.

\subsection{The Content}

The cretulae are one of the main Aegean administrative systems used by the Minoan Palaces. They are small clay nodules bearing the impression of a seal and, in most cases, an inscribed sign of the Cretan script, the Linear A.

We have gathered in two correlated catalogues all the information concerning the various aspects of these objects. The 175 numbers of Cat. A (Nrs. 1-175) focus each one on a different seal (Fig. 4) which may be impressed on different cretulae $^{3}$ but give further information, many of which we may find also in Cat. B. This latter Catalogue is based on the carved symbols ${ }^{4}$ : the single numbers (Nrs. 1-179) concern the whole of the cretulae which have the same sign and the same impressed seal (Fig. 5).

As to the cretulae discussed in MUSINT II (i.e. the sealed documents kept in the two Italian Museums) we have the opportunity to present not only the images kindly offered by ARACHNE/CMS, but also 3/D models that our team created with laser scanner acquisition and uploaded on the Sketchfab platform (see next paragraph on technical devices).

\footnotetext{
${ }^{2}$ The references on this subject are extremely extensive. We limit quotations to some of the most inclusive works on cretulae and for an exhaustive bibliography we refer to the work in press by Montecchi [33].

${ }^{3}$ The text of reference is the Corpus der Minoischen und Mykenischen Siegel, Band II, Teil 6 [34]; for a revised version of the whole Corpus, the website ARACHNE (http://arachne.uni-koeln.de/), with a part devoted to the Aegean seals and sealings (http://arachne.uni-koeln.de/drupal/?q=it/node/271), is now available online.

${ }^{4}$ The point of reference for the signs incised on the cretulae remains GORILA 2 [12]. It is also important to consider the more recent work by Hallager [13] specifically devoted to the "roundel" shape, but with major references to the other sealed documents.
} 


\begin{tabular}{|c|c|c|}
\hline No. Cat. B & 101 & CARVED LINEAR A SIGN \\
\hline No. GORILA & Wa 1557.1592 & \\
\hline Linear AB sign(s) & $A B S I \mathrm{KU}$ & \\
\hline Occurrences & 35 & \\
\hline Seribe & $\begin{array}{l}\text { Wa } 90 \text { (MAF, HMs 461/1-17) } \\
\text { Wa } 86 \text { (RMP) } \\
\text { Wa } 91(\mathrm{HMs} 461 / 18-19.21) \\
\text { Wa } 84(\mathrm{HMs} \mathrm{461/20)} \\
\text { Wa } 92(\mathrm{HMs} \mathrm{462/1-6)} \\
\text { Wa } 93(\mathrm{HMs} 463 / 2)\end{array}$ & \\
\hline Shape & single-hole hanging nodule & \\
\hline No. AT/Levi (HT) & HT 19 & \\
\hline Museums & \multicolumn{2}{|c|}{ MAF 94759. 94760; RMP 71964.71966.71965; HMS 461/1-24; HMS 462/1-6; HMs 463/2 } \\
\hline No. CMS II,6 & \multicolumn{2}{|l|}{117} \\
\hline No. Cat. A & \multicolumn{2}{|l|}{117} \\
\hline Sealing motif & A standing water bird tc & left, surrounded by vegetal motifs. \\
\hline Notes & \multicolumn{2}{|c|}{$\begin{array}{l}\text { In GORILA } 2 \text { the cretula MAF } 94759 \text { is catalogued as "Firenze } 3 \text { " and the MAF } 94760 \text { as "Firenze } 4 \text { "; the cretula RMP } \\
71964 \text { as "Pigorini } 2 \text { ", the RMP } 71966 \text { as "Pigorini } 18 \text { " and the RMP } 71965 \text { as "Pigorini } 21 \text { ". }\end{array}$} \\
\hline
\end{tabular}

Fig. 5 Example of a Cat. B number

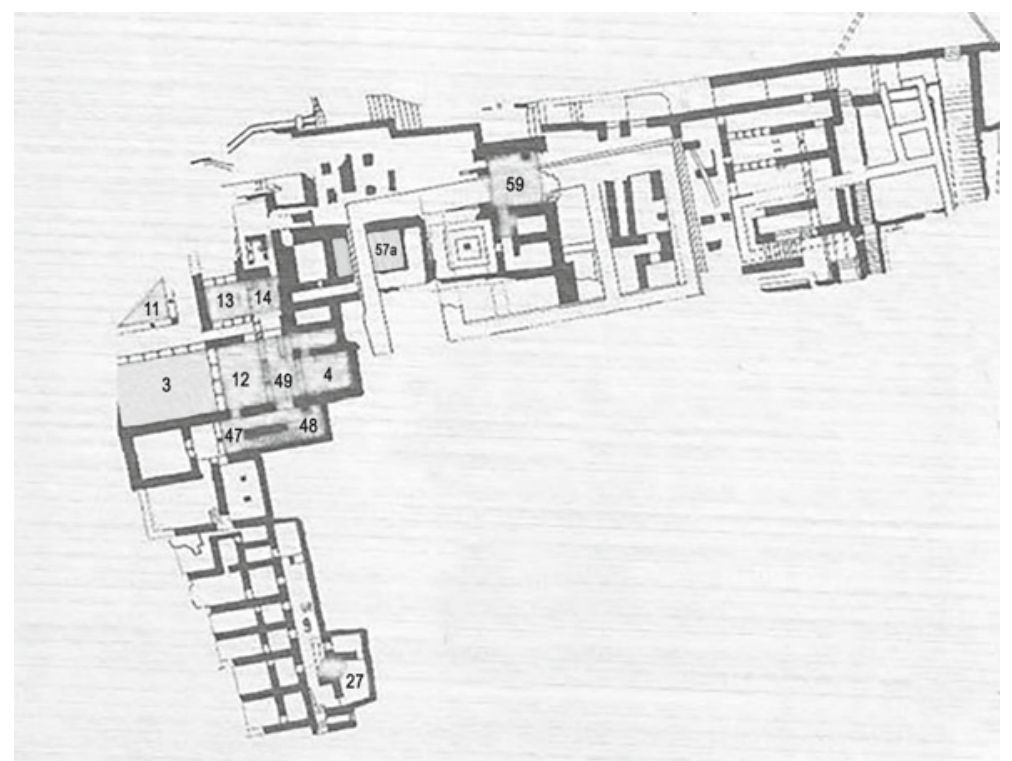

Fig. 6 The Villa of Haghia Triada

These objects were found in different parts of the Villa (Fig. 6). We shall limit to describe three areas where cretulae have been found, since the exact localization of the documents is still under discussion ([33], with exhaustive bibliography), apart from a very limited portion whose original position has been reconstructed:

(1) SW Quarter. This is the only area inside which an exact placing may be given: on the threshold or window-sill between room 27 and corridor 9, 45 dome noduli, without inscription but stamped by the same seal (Cat. A No. 20) have been found. 
(2) NW Quarter. In this exclusive quarter various groups of cretulae have been found, but a reconstruction of their original location, partly at the first floor and partly at the ground floor, is difficult because the layout of the rooms was not clear since the beginning of the excavations. A more general differentiation has been made on the basis of the discovery of the objects on smaller distinguished areas: one of them includes rooms 4-49-12 and 47-48, where likely the objects had fallen down from above or slipped from near areas; a second area includes room 13 (the so-called 'stanza dei sigilli') and the adjacent corridor 50; a third area, not well distinguished from the previous one, includes porch 11.

(3) N Quarter. In the area of northern magazines, where the major group of Linear A tablets has been found, also some nodules and/or noduli have been discovered. The identification of a specific room (room 59) remains uncertain since the same structure of the room, mostly destroyed by the following construction of the Mycenaean megaron, is not clearly defined.

These Catalogues and the related Database represent the starting point to enter new and diversified routes by means of distinct but connected queries, which try to answer as many questions as possible. This relational database gives information about shape, motifs, inscriptions and so on of single objects; offers queries to correlate such information from both files of stamped and incised motifs, and gives also statistical data (percentages, recurrences, etc.). In this way, it allows extensive and overlapping cross-correlations that can lead to new interpretations of both seals and written signs. In the next paragraph the technical aspect will be briefly described.

\subsection{Technical Devices}

The first step of elaboration from these two distinct data sets, which differ from each other in some entries, is the creation of a table that gathers the information for all the items. Each string corresponds to a single object and is the union of the information from both the data sets/catalogues (seal impression and carved sign). Each object has been identified with a couple of identification numbers (IDs): the first represents the number of the objects inside each catalogue and the second represents the number of the catalogue itself. In this way, it is possible to make a query to identify only the information for this object from one or the other data set.

The second step is the creation of tables to be used to implement direct queries, or first-level queries. A table has been constructed for every search parameter. The tables relate the search parameter and the objects of the catalogues. Each parameter has been associated to a number and the iconographies have been associated to each object through this list of numbers (Fig. 7). 
Fig. 7 Example of numbers associated to iconographic motifs

\begin{tabular}{|c|c|c|}
\hline id & db1_icon_name_IT $\Delta$ & db1_icon_name_EN \\
\hline 32 & - & - \\
\hline 5 & animali & animals \\
\hline 34 & animali - animali marini & animals - sea animals \\
\hline 35 & animali - animali marini - pesci, altro & animals - sea animals - fishes, others \\
\hline 37 & animali - animali marini e insetti & animals - sea animals and insects \\
\hline 15 & animali - insetti & animals - four-footed animals - insects \\
\hline 13 & animali-pesci & animals - four-footed animals - fishes \\
\hline 6 & animali - quadrupedi & animals - four-footed animals \\
\hline 8 & animali - quadrupedi - bovini & animals - four-footed animals - bovines \\
\hline 11 & animali - quadrupedi - cani & animals - four-footed animals - dogs \\
\hline 9 & animali - quadrupedi - capridi & animals - four-footed animals - caprids \\
\hline 12 & animali - quadrupedi - cavalli & animals - four-footed animals - horses \\
\hline 10 & animali - quadrupedi - cervidi & animals - four-footed animals - cervids \\
\hline 7 & animali - quadrupedi - leoni & animals - four-footed animals - lions \\
\hline 33 & animali - quadrupedi - suini & animals - four-footed animals - boars \\
\hline 16 & animali-scimmie & animals - four-footed animals - monkeys \\
\hline 14 & animali - uccelli & animals - four-footed animals - birds \\
\hline 18 & creature immaginarie & imaginary creatures \\
\hline 20 & creature immaginarie - donna uccello & imaginary creatures - bird-woman \\
\hline 19 & creature immaginarie - genio minoico & imaginary creatures - Minoan genuis \\
\hline 22 & creature immaginarie - grifone & imaginary creatures - griffin \\
\hline 21 & creature immaginarie - sfinge & imaginary creatures - sphinx \\
\hline 1 & esseri umani & humans \\
\hline 3 & esseri umani - figura femminile & humans - woman \\
\hline 2 & esseri umani - figura maschile & humans - man \\
\hline
\end{tabular}

The example here is about iconography of the impressed seal: to the left, the structure of the table, and to the right the associated research form. As one can see, in the table each motif has a different number.

This is the basis for a further step.

The third step is the creation of correlation tables, to be used for the crossed queries or second-level queries. These tables allow the crossed correlation of data, so that multiple research options can be combined (Fig. 8).

In the correlation table each ID can appear various times, since it aims to allow all the possible variations of a certain element, or to combine different characteristics of the same object.

Particularly, the figure shows the correlations of the iconographies where information about their distribution among the objects in both catalogues may be obtained.

The general behaviour of the database is managed by the programming language. The suffix _IT or _EN to the table names allows the automatic selection of the language by PHP scripts (postprocessing hypertext protocol). This is one of the most used programming language and has been selected as the most suited interface with the SQL structure of the database. 
Fig. 8 Example of correlation tables

\begin{tabular}{|r|r|r|r|}
\hline id & ncat & tcat & nicon \\
\hline 1 & 1 & 1 & 3 \\
\hline 2 & 1 & 1 & 29 \\
\hline 3 & 2 & 1 & 29 \\
\hline 4 & 2 & 1 & 3 \\
\hline 5 & 3 & 1 & 3 \\
\hline 6 & 3 & 1 & 29 \\
\hline 7 & 4 & 1 & 3 \\
\hline 8 & 4 & 1 & 29 \\
\hline 9 & 5 & 1 & 3 \\
\hline 10 & 5 & 1 & 29 \\
\hline 11 & 6 & 1 & 3 \\
\hline 12 & 6 & 1 & 29 \\
\hline 13 & 7 & 1 & 2 \\
\hline 14 & 7 & 1 & 29 \\
\hline 15 & 8 & 1 & 2 \\
\hline 16 & 8 & 1 & 3 \\
\hline 17 & 8 & 1 & 29 \\
\hline 18 & 9 & 1 & 3 \\
\hline 19 & 9 & 1 & 2 \\
\hline 20 & 9 & 1 & 29 \\
\hline 21 & 10 & 1 & 2 \\
\hline 22 & 10 & 1 & 3 \\
\hline 23 & 10 & 1 & 29 \\
\hline 24 & 11 & 1 & 2 \\
\hline 25 & 11 & 1 & 29 \\
\hline & & \\
\hline
\end{tabular}

Some data sheets embed link to interactive 3D images, coming from the platform SketchFab (https://sketchfab.com/). HTML/PHP code has been embedded into the web pages in order to retrieve information from SketchFab remote archives. Meanwhile SQL queries have been written to read information from SketchFab and some tables have been customized for this aim. The database has been connected to the 3D model in SketchFab to give flexibility to the content of the web pages, the carved signs and the seal impressions. SketchFab is perfectly inserted in the context of Musint II for the interactive experience it offers. 


\section{DB-TWC (Acronym for Textile Work Areas in Bronze Age Crete)}

Other data bases have been already realised in DBAS and have been already presented in press. Some more are still under construction and we hope to implement the range of addressed topics in the future. Presently, another quite complex data base that is still in progress is the DBAS-TWC, on textile work areas of Bronze Age Crete. The aim of the work is to move a step further beyond current scholarship, that is mainly concerned with the technical details of tools and craftsmanship to reconstruct the actual textiles being produced then. This is a quite developed domain and our understanding of the Minoan textile techniques has considerably improved in the last decade $[1-3,6,7,9,10,22,31,36]$. However, a comprehension of the wider organisation of textile production is still missing, as it is a reappraisal of the interconnections among various production cycles of the agricultural and domestic economies within their own setting.

One of the main obstacles is that the evidence is widespread throughout the many and dispersed sites of the island, that are investigated and published in a variety of ways and languages. The lack of uniformity is thus the main scientific issue. How can we compare things that are not homogeneous? That is why the data base has been created. It aims to provide an unified and homogeneous data set of the evidence related to textile activities from Bronze Age Crete, re-organising the information from a variety of publications and languages. The effort has been made to create a grid of indicators to be applied to every context taken into account.

Actually, one of the most important factor to be considered is that in a number of the relevant contexts indicators of various activities are found together: liquid processing, food processing and cooking, storage and textile production. Many tools are multi-purpose, other very specialised. This suggests a real mixed use of spaces in antiquity $[3,8,11,41]$. The documented textile activities are only part of the productive processes carried on the examined work areas. One of the aim of the DB is to explore the way all these implements overlap, what can mirror the different types of activity organisation in the various considered contexts. We also intend to propose a preliminary typological classification of the analysed contexts and a first differentiation between various scales of production (Figs. 9 and 10).

As result, the record for each single entry/context is quite complex, since it contains not only the information related to textiles, but also those connected to the other spheres of activity. It includes:

(a) Site identification: name, chronology, exact context (if a room or a group of rooms, and not a whole structure, are concerned), bibliography and special notes.

(b) Functional specialisation: presence or absence of the following indicators:

(1) dye-stuffs; mordents or other chemical substances;

(2) liquid processing installations and tools: considerable variations are possible; 
(a)

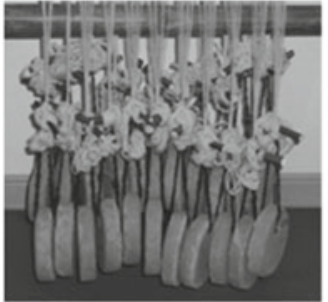

(b)

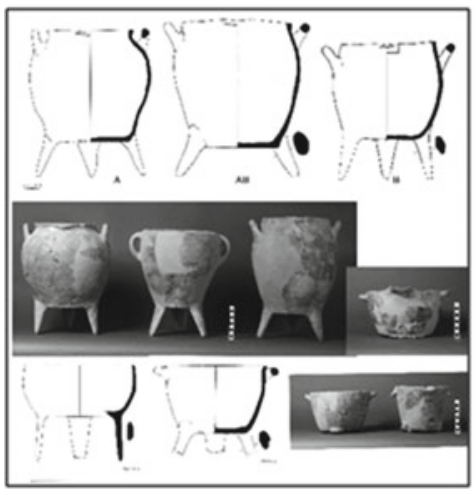

(c)
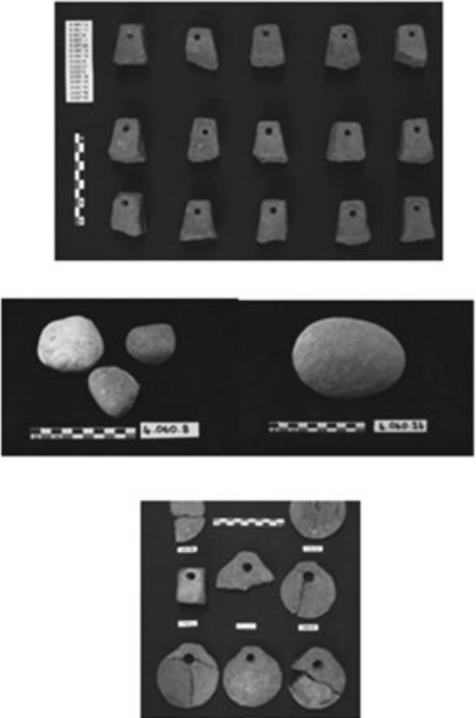

Fig. 9 a Experimental loom set up with replicas of Minoan loomweights (modified from Andersson Strand-Nosch [6, Fig. 4.1.17, p. 90]); b cooking pots from Petras, Crete, LMI (Alberti [4, Fig. 1]); c loomweights and stone tools from Sector Pi, Malia, Crete (courtesy of Efa, M. Pomadère)

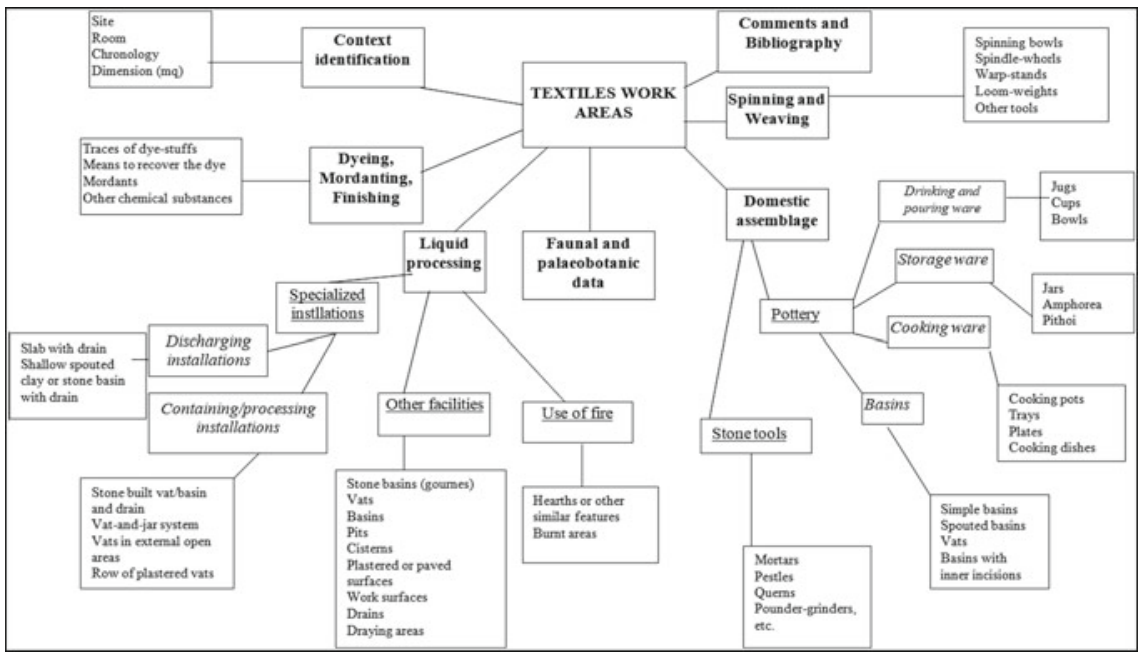

Fig. 10 DBAS-TWC — sectors of activity and relevant archaeological indicators to be considered 


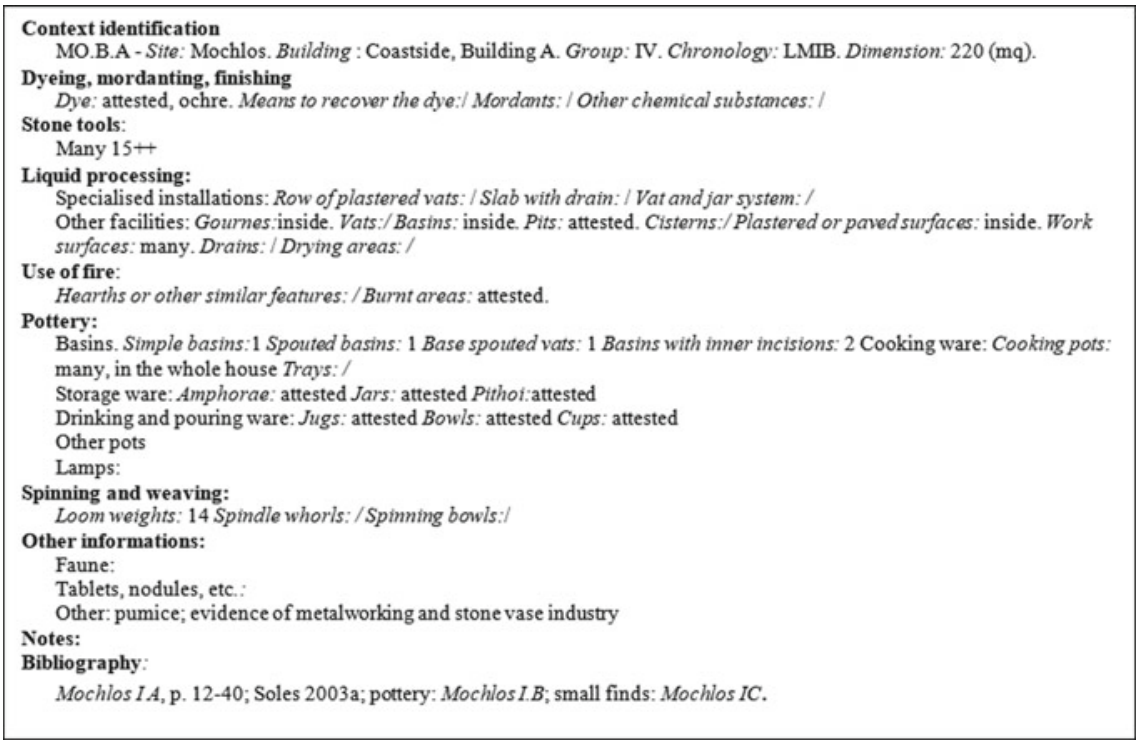

Fig. 11 DBAS-TWC — example of the various fields of a single context/file

(3) typical domestic assemblage (cooking and storage vessels, stone tools, hearths, etc.);

(4) textile tools proper (spindles, spinning bowls, spindle-whorls, loomweights);

(5) other.

The search to be implemented in this DB will be then quite complex. It would be necessary to intersect every indicator with the others, to see how implements of the various activity sectors overlap. Are always liquid processing and textile tools together? Are large pots and dye-stuff in the same spot, as to suggest dyeing operations? What can we say about the organisation of craftwork? Are there larger and more specialised areas than the others?

We are still at the very beginning, but we hope that the experience we are making with the DB-HTS on cretulae will help us to reach the desired result (Fig. 11).

\section{The Tale La Mattina Di Zuzù (Zuzù's Morning)}

The last example we would like to illustrate here is the tale La mattina di Zuzù (Zuzù's morning). It is an interactive tale for children and has been planned as educational device linked to MUSINT II, where the Minoan cretulae are the main focus. The tale takes place in Haghia Triada, Crete, during the Bronze Age and features as main characters the joung girl Zuzù, her friends Bri Bri and Pim and the Secretary of the 


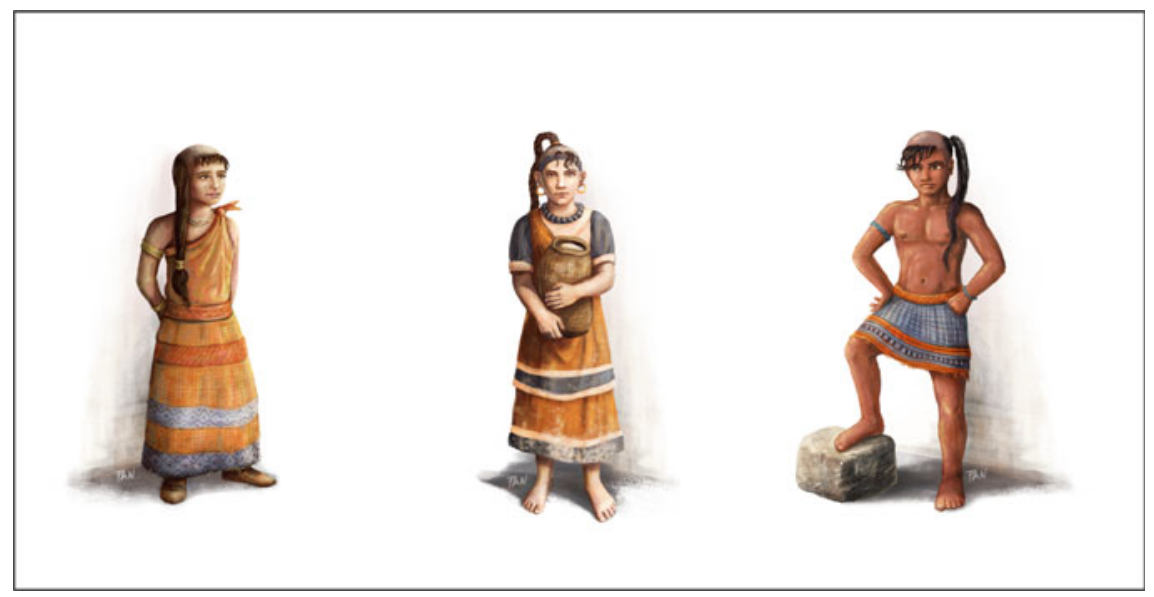

Fig. 12 The main character of the tale: from left, Zuzù, Bri Bri and Pim (P. Kruklidis)

'Villa'. During the morning, Zuzù and her friends help weavers and grinders, admire frescoes, interact with the Secretary, store-keepers and other administrators, and, last but not least, discover various cretulae that have been lost, helping in this way the Secretary and the Lord of the 'Villa' to solve a mystery [5]. The tale could give some hints on the 'best practices' for Digital Cultural Heritage (Fig. 12).

The first point to stress is the strict connection among the tale and the databases presented in our sites. The idea is to take the various items that are part of the scientific DBs in our websites and to represent them in use, to show the audience a possible slice of ancient life. In this way, the somehow inert material culture so often quite aridly recorded acquires vitality and scope, and inscribes the more abstract informatics tools within a framework of practices and sense.

This process is grounded on the extreme accuracy of the scientific documentation: each step of Zuzù and his friends has precise archaeological references, both in the archaeological remains and in specialised publications. The frescoes they admire are exactly those found in the "Villa", and the wool-store is exactly where some administrative documents concerning wool have been found [23-32, 35, 37-40]. However, and this is the great challenge for the archaeologist/narrator, the tale goes on as a tale, with no scientific details or footnotes: all the relevant information has been embedded in the narration (Fig. 13).

Interaction is the key for a good "edutainment" result. The users must act and be stimulated by the story, assimilating in the meanwhile the various details on the ancient life. That is why the tale is interactive. It has four sections, three linked to different seal imprints and having Zuzù as main character, and a fourth one for the Secretary. Each section can be read independently. The reader can move from one section to the other, answer questions, follow links to educational materials and play games. Last but not least, the end of the tale is open: it is up to the reader to decide the finale. 


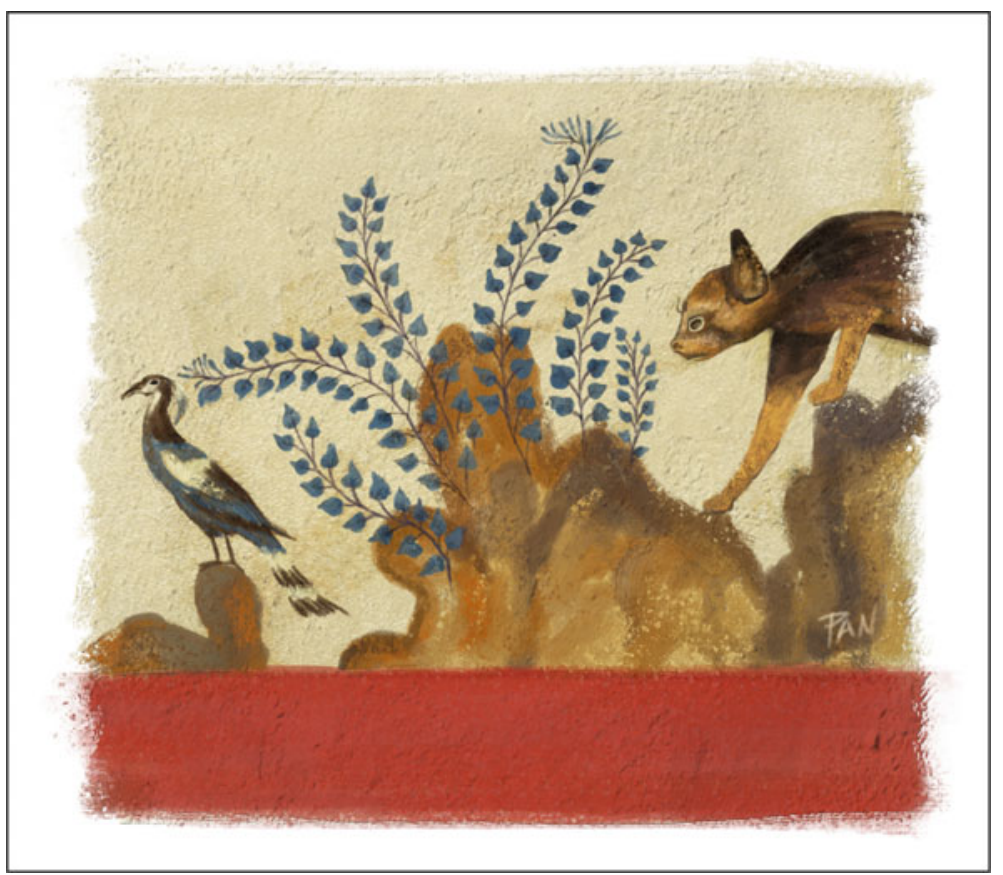

Fig. 13 The most famous fresco from Haghia Triada, the cat chasing a bird, as appears in the online tale (P. Kruklidis)

These features have been achieved by a smart use of links. They allow the characters to make decisions and the reader may hop through several points of the story. The way we choose to present the tale and the archaeological and historical contents are multi-media graphics: hand-drawing, vector images, virtual reconstructions and others, 2D and 3D reconstructions, pictures and reproductions of remains and archaeological materials. Thanks to this, the story is more attractive and educational sections are more informative and complete (Fig. 14).

Collaboration is obviously the key-word to achieve such a complex result. The tale as it is online now is the outcome of the work of the archaeologist/narrator, the illustrator, the IT specialist and the game-makers. Each page has been reworked many times, especially to tune illustrations and the various links to educational materials. We had discussions on the hair-style of children, on the age of characters, on the right clothes for a scribe and for a Lord. We actually learned a lot, building a learning resource. 


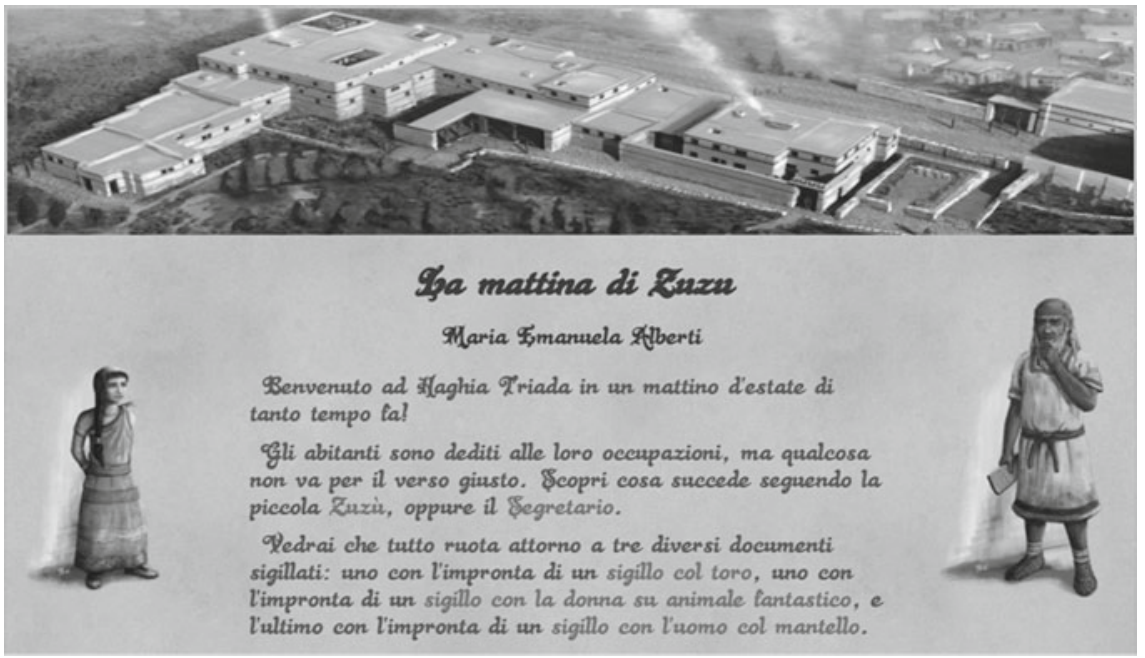

Fig. 14 The beginning of the tale. Zuzù on the left and the Secretary on the right. Above, the reconstruction of the 'Villa' of Haghia Triada (P. Kruklidis)

\section{Conclusions}

These three examples of our work to implement the DBAS and MUSINT websites underline the role that new technologies can play even for the study of these remote ages and societies. Three aspects are worth of note:

1. strict connection between academic research and the creation of online contents

2. interaction between research and didactic issues

3. cooperation of various institutions and different specialists, such as archaeologists, philologists, school teachers, illustrators, IT specialists and game-makers. Cooperation is indeed, in our opinion, one of the best asset of the Digital Cultural Heritage. 


\section{References}

1. Alberti, M.E.: The Minoan Textile Industry and the Territory from Neopalatial to Mycenaean Times: some First Thoughts. Creta Antica 8 (2007) 243-263

2. Alberti, M.E.: Textile Industry Indicators in Minoan Work Areas: Problems of Typology and Interpretation. In: Alfaro, C., Karali, L. (eds): Vestidos. textiles y tintes. Estudios sobre la producción de bienes de consumo en la Antigüedad. Actas del II Symposium Internacional sobre Textiles y Tintes del Mediterráneo en el mundo antiguo (Atenas. 24 al 26 de noviembre. 2005). Purpureae Vestes II. Universitàt de València: València (2008) 25-36

3. Alberti, M.E.: La casa., la villa, il palazzo. Organizzazione produttiva a Creta in età neopalaziale e micenea (vino, olio, cereali e tessuti). Anicia: Roma (2012a)

4. Alberti, M.E.: Vessels in Cooking Fabrics from Petras House I(LMIA): Overview and Capacity Measures. In: Tsipopoulou, M. (ed.): Petras, 25 Years of excavations and studies. Acts of a two-days conference held at the Danish Institute at Athens, 9-10 October 2010. Monographs of the Danish Institute in Athens 16. The Danish Institute in Athens: Athens (2012b) 235-254

5. Alberti, M.E.: L'impatto del 'racconto' interattivo sull'insegnamento della storia. In: Jasink, A.M., Dionisio, G. (eds): MUSINT II. Nuove esperienze di ricerca e didattica nella museologia interattiva. Periploi 8. Firenze University Press: Firenze (2016) 53-66

6. Andresson Strand, E., Nosch, M.-L. (eds): Tools. Textiles and Contexts. Investigating Textile Production in the Aegean and Eastern Mediterranean Bronze Age. Ancient Textiles Series, vol. 21. Oxbow Books: Oxford - Philadelphia (2015)

7. Burke, B.: From Minos to Midas: Ancient Cloth Production in the Aegean and the Anatolia. Ancient Textiles Series, vol. 7. Oxbow Books: Oxford - Oakville, Conn (2010)

8. Costin, C.L.: Craft Specialization: Issues in Defining, Documenting and Explaining the Organization of Production. In: Schiffer, M.B. (ed.): Archaeological Method and Theory, vol. 3. University of Arizona Press: Tucson (1991) 1-56

9. Cutler, J.: Ariadne's Thread: the Adoption of Cretan Weaving Technology in the Wider Southern Aegean in the Mid-Second Millennium BC. In: Nosch, M.L., Laffineur, R. (eds): KOSMOS. Jewellery, Adornment and Textiles in the Aegean Bronze Age, Proceedings of the $13^{\text {th }}$ International Aegean Conference, University of Copenhagen, Danish National Research Foundation's Centre for Textile Research, 21-26 April 2010. Aegaeum 33. Peeters: Leuven and Liège (2012) $145-154$

10. Cutler,. J., Andersson Strand, E., Nosch, M.-L.: Textile production. In: Poursat, J.-C.: Vie quotidienne et techniques au Minoen Moyen II. Outils lithiques. poids de tissage. lampes. divers. Faune marine et terrestre. Fouilles exécutées à Malia. Le Quartier Mu V. Études crétoises, vol. XXXIV. Ecole française d'Athènes: Athènes (2013) 95-120

11. Evely, R.D.G.. Minoan Crafts: Tools and Techniques. An Introduction. Studies in Mediterranean Archaeology, vol. 92. P. Åströms Förlag: Göteborg and Jonsered (1993-2000)

12. Godart, L., Olivier, J.-P.: GORILA 2 - Recueil des Inscriptions en Linear A. Vol. 2. Nodules, scellés et rondelles édités avant 1970. Études Crétoises, vol. XXI,2. Paul Geuthner: Paris (1979)

13. Hallager, E.: The Minoan Roundel and other Sealed Documents in the Neopalatial Linear A Administration, Vols II. Aegaeum 14. Peeters: Liège et UT-PASP (1996)

14. Jasink, A.M., Baldi, M., Bombardieri, L., Carminati, F., Gonzato,F.: Collecting Databases about Aegean Subjects on-line (DBAS Project). Kadmos XLI (2006) 173-186

15. Jasink, A.M., Bombardieri, L., Gonzato, F.: New reaserch tools for the Aegean Studies. The DBAS project on-line. DO-SO-MO. Fascicula Mycenologica Polona 7 (2007) 81-92

16. Jasink, A.M., Bombardieri, L., Marino, M.: The Ahhiyawa Question and the Cretan Hieroglyphic Seals: two Databases in the DBAS project. In Pecchioli Daddi, F., Torri, G., Corti, C. (eds): Central-north Anatolia in the Hittite period: New Perspectives in light of recent Research, Acts of the International Conference held at the University of Florence (7-9 February 2007). Herder: Roma (2009) 249-257, pl. XXX-XXXII

17. Jasink, A.M., Dionisio, G. (eds.): MUSINT 2. Nuove esperienze di ricerca e didattica nella museologia interattiva. Periploi 8. Firenze: Firenze University Press (2016) 
18. Jasink, A.M., Dionisio, G.: Teaching New Technological Methodologies Applied to Ancient History: the Profitable Example of the Municipal Archaeological Museum and the Primary School of Montelupo Fiorentino, Italy. In: Proceedings of the 20th International Conference on Cultural Heritage and New Technologies (CHNT 20), November 4-6 2015 Wien, Wien (2015)

19. Jasink, A.M., Faralli, C., Kruklidis, P.: MUSINT II: A Complex Project on a Virtual and Interactive Museum Involving Institutions in Florence, Rome and Heraklion. Studies in Digital Heritage, Vol. 1, No. 2. Wien (2017) 283-297

20. Jasink, A.M., Tucci, G., Bombardieri, L. (eds): MUSINT. Periploi 3. Firenze University Press: Firenze (2011)

21. Jasink, A.M., Tucci, G., Cini, D.: MUSINT: A Virtual Habitat for Relocated Archaeological Artifacts. In Borner, W., Uhlirz, S., Dollhofer, L. (eds): Proceedings of the 16th International Conference on Cultural Heritage and New Technologies, November 14-16 2011 Wien (CHNT 16). Wien (2012) 185-200

22. Jones, B.: Ariadnes's Threads. The Construction and Significance of Clothes in the Aegean Bronze Age. Aegaeum 38. Peeters: Leuven-Lièges (2015)

23. La Rosa, V.: La Villa Royale de Haghia Triada. In: Hägg, R. (ed.): The Function of the 'Minoan Villa': Proceedings of the Eighth International Symposium at the Swedish Institute of Athens. 6-8 June. 1992. Skrifter utgivna av Svenska Institutet i Athen $4^{\circ}$. Svenska Institutet i Athen and Jonsered: Stockholm. Distributor P. Åströms Förlag (1997) 79-89

24. La Rosa, V.: "Il colle sul quale sorge la chiesa ad ovest è tutto seminato di cocci". Haghia Triada. Vicende e temi di uno scavo di lungo corso. Creta Antica 4 (2003) 11-68

25. La Rosa, V.: La fornace da vasaio TM IB di Haghia Triada. Introduzione. Creta Antica 12 (2011) 127-130

26. La Rosa, V.: La conclusione dei lavori ad Haghia Triada. Creta Antica 15 (2014) 129-241

27. Militello, P.: Haghia Triada I. Gli affreschi. Monografie della Scuola Archeologica di Atene e delle missioni italiane in Oriente IX. Bottega d'Erasmo: Padova (1998)

28. Militello, P.: Ayia Triada Tablets, Findspots and Scribes. A Reappraisal. Pasiphae Rivista di filologia e antichità egee 5 (2011) 59-69

29. Militello, P.: La fornace da vasaio TM IB di Haghia Triada. Una riconsiderazione della tavoletta HT 31. Creta Antica 12 (2011) 273-288

30. Militello, P.: Impianti di lavorazione a Festòs ed Haghia Triada in età palaziale: per una rassegna delle evidenze. Creta Antica 13 (2012) 109-138

31. Militello, P. Festòs e Haghia Triada: i rinvenimenti minori I. Materiali per la tessitura. Studi di archeologia cretese, vol. 11. Bottega d'Erasmo A. Ausilio: Padova (2014)

32. Montecchi, B.: Planning a Feast in Neopalatial Crete: A Look at the Linear A Evidence. Annuario della Scuola Archeologica di Atene e delle missioni italiane in Oriente LXXXIX.1 (2011) 111-133

33. Montecchi, B.: Contare a Haghia Triada. Le tavolette in Lineare A, i documenti sigillati e il sistema amministrativo nel TM IB (in press)

34. Müller, W., Pini, I.: CMS II,6 - Corpus der Minoischen und Mykenischen Siegel. Die Siegelabdrücke von $\mathrm{Aj}$. Triada und anderen zentral-und ostkretischen fundorten. Gebr. Mann Verlag. Berlin (1999)

35. Palio, O.: Le Case del Lebete e la Case delle Sfere Fittili ad Haghia Triada. Creta Antica 3 (2002) 121-132

36. Peterson Murray, S.: Patterned Textiles as Costume in Aegean Art. In: Shaw, M.C., Chapin, A.: Woven Threads. Patterned Textiles of the Aegean Bronze Age. Ancient Textiles Series, vol. 22. Oxbow Books: Oxford and Havertown, PA (2016) 43-104

37. Procopiou, H., Treuil, R. (eds): Moudre et broyer. L'interprétation fonctionnelle de l'outillage de mouture et de broyage dans la Préhistoire et l'Antiquité I-II. CTHS: Paris (2002)

38. Puglisi, D.: L'organizzazione a terrazze nel "villaggio" TM I di Haghia Triada.Creta Antica 8 (2007) 169-200

39. Puglisi, D.: La fornace da vasaio TM IB di Haghia Triada. Le ceramiche e il sistema di produzione. distribuzione e consumo. Creta Antica 12 (2011) 199-272 
40. Tomasello, F.: La fornace da vasaio TM IB di Haghia Triada. L'impianto. Creta Antica 12 (2011) 131-198

41. Tournavitou, I.: Towards an Identification of a Workshop Space. In: French, E.B., Wardle, K.A. (eds): Problems in Greek Prehistory. Papers presented at the Centenary Conference of the British School of Archaeology at Athens. Manchester April 1986. Bristol Classical Press: Bedminster, Bristol (1988) 447-468 